available online http://jurnal.um-tapsel.ac.id/index.php/nusantara/index

\title{
PENERAPAN STRATEGI PEMBELAJARAN EKSPERIMEN TERHADAP MINAT BELAJAR PESERTA DIDIK DI KELAS X SMA NEGERI I BATANGTORU
}

\author{
Uli Anto Hutagalung1), Riski Baroroh,2) , Rahmat Pramudya3) \\ 1,2,3) FKIP Universitas Muhammadiyah Tapanuli Selatan
}

\begin{abstract}
Abstrak
Rumusan masalah dalam penelitian ini adalah Apakah dengan adanya Penerapan Strategi pembelajaran Eksperimen dapat meningkatkan minat belajar dalam mata pelajaran ekonomi pada materi manajemen peserta didik di kelas X SMA Negeri 1 Batangtoru,dan yg menjadi tujuan penelitian ini adalah untuk mengetahui adanya peningkatan Penerapan Strategi Pembelajaran Eksperimen yang dilakukan oleh pendidik dan meningkatnya Minat belajar peserta didik dan untuk mengetahui kemampuan tenaga pendidik dalam mengolah pembelajaran dengan Penerapan Strategi Pembelajaran Eksperimen.

Dalam penelitian ini menggunakan metode penelitian Asosiatif yaitu dengan pendekatan pengumpulan data yang penulis lakukan yaitu penyebaran angket Strategi Pembelajaran Eksperimen dan angket Minat belajar peserta didik. Kemudian untuk melihat Apakah dengan Penerapan Strategi Pembelajaran Eksperimen Terhadap Minat Belajar Peserta Didik Dalam Mata Pelajaran Ekonomi Pada Materi Manajemen Di Kelas X SMA Negeri 1 Batangtoru .
\end{abstract}

Kata Kunci: Strategi Pembelajaran Eksperimen, Minat Belajar, SMA Negeri 1 Batangtoru

*Correspondence Address : uli.anto@um-tapsel.ac.id DOI : $10.31604 /$ jips.v6i2.2019.214-220

(C) 2019 Fakultas Keguruan \& Ilmu Pendidikan UM-Tapanuli Selatan 


\section{Pendahuluan}

Pendidikan memiliki peranan penting dalam mempersiapkan sumber daya manusia yang berkualitas, oleh karena itu, pendidikan hendaknya dikelola, baik secara kualitas maupun kuantitas. Hal tersebut bisa tercapai apabila peserta didik dapat menyelesaikan pendidikan tepat pada waktunya dengan hasil belajar yang baik. Guru sangat dituntut untuk mampu mengelola kelas ketika mengajar. Salah satunya mampu menciptakan susana yang tertib ketika berlangsungnya kegiatan proses pembelajaran. Kalau peserta didik tidak tertib maka guru harus berusaha seoptimal mungkin untuk menertibkannya, kelas yang tertib akan menciptakan suasana pembelajaran yang baik.

Guru merupakan jabatan atau profesi yang memerlukan keahlian khusus sebagai guru. Pekerjaan ini tidak bisa dilakukan orang yang tidak memiliki keahlian untuk melakukan kegiatan atau pekerjaan sebagai guru. Orang yang pandai berbicara dalam bidang-bidang tertentu, belum dapat disebut sebagai guru. Untuk menjadi guru diperlukan syarat-syarat khusus, apalagi sebagai guru yang profesional yang harus menguasai betul seluk beluk pendidikan dan pengajaran dengan berbagai ilmu pengetahuan lainnya yang perlu dibina dan dikembangkan mulai masa pendidikan tertentu atau pendidikan prajabatan.

Dalam proses pendidikan, didalamnya harus terdapat minat, akan tetapi bila hal ini tidak diperankan dengan baik oleh guru seorang peserta didik tidak akan mempunyai semangat untuk melakukan aktivitas belajar. Dalam proses belajar minat sangat diperlukan, sebab seseorang yang tidak mempunyai minat belajar dalam dirinya, tidak akan mungkin melakukan aktivitas belajar. Hal ini merupakan pertanda bahwa sesuatu yang akan dikerjakan itu tidak memenuhi kebutuhannya.

Banyak anak dengan intelegensi yang rendah disebabkan tidak ada minat dalam belajar. Fungsi minat yang seharusnya sebagai pendorong, penggerak, dan pengarah perbuatan belajar tidak dijalankan dengan baik. Dalam kegiatan belajar-mengajar, apabila ada peserta didik misalnya tidak berbuat sesuatu yang seharusnya dikerjakan, maka perlu diselidiki sebabsebabnya. Sebab-sebab itu biasanya bermacam-macam, mungkin ia tidak senang, mungkin sakit, lapar, ada masalah pribadi dan lain-lain. Hal ini berarti pada diri anak tidak terjadi 
perubahan energi, tidak terangsang afeksinya untuk melakukan sesuatu, karena tidak memiliki tujuan atau kebutuhan belajar. Keadaan semacam inilah perlu dilakukan daya upaya yang dapat menemukan sebab musababnya dan kemudian mendorong seorang peserta didik itu mau melakukan pekerjaan yang seharusnya dilakukan, yakni belajar.

Minat merupakan kecendrungan hati yang sangat tinggi terhadap sesuatu, minat mempunyai peranan penting dalam kegiatan belajar, minat mempunyai kaitan yang erat dengan motivasi peserta didik yang memiliki minat terhadap sesuatu bidang studi tertentu cendrung tertarik perhatiannya dan dengan demikian timbul motivasinya untuk mempelajari bidang studi tersebut.

Minat juga dipengaruhi oleh nilainilai yang dianggap penting dalam kehidupannya. Perubahan nilai-nilai yang dianut akan mengubah tingkah laku manusia dan minatnya. Karenanya, bahan-bahan pelajaran yang disajikan hendaknya disesuaikan dengan minat peserta didik dan tidak bertentangan dengan nilai-nilai yang berlaku dalam masyarakat.

Strategi pembelajaran eksperimen ini mengajak para peserta didik untuk lebih berperan dan mandiri dalam memahami apa yang mereka pelajari. Aktivitas belajar peserta didik akan lebih banyak karena bukan saja hanya mendapatkan pelajaran dari guru melainkan juga mendapatkan ilmu pelajaran dari eksperimen (percobaan) yang mereka lakukan sehari-hari. Dengan begitu peserta didik mayoritas akan lebih mengerti dalam proses pembelajaran dan pada akhirnya minat belajar peserta didik juga dapat meningkat. Sebagai pendidik, penulis melihat bahwa yang sering terjadi selama ini adalah pembelajaran yang berlangsung kurang efektif dan kurang melibatkan peserta didik dan kecenderungan menggunakan metode ceramah sehingga terkesan membosankan bagi peserta didik.

Masalah dalam penelitian ini pakah dengan adanya penerapan strategi pembelajaran eksperimen dapat meningkatkan minat belajar dalam mata pelajaran ekonomi di SMA NEGERI 1 BATANGTORU. Dengan penuh harapan bahwa nantinta akan dapat bermamfaat bagi sekolah, guru dan peserta didik.

\section{Metode Penelitian}

Penelitian ini di SMA Negeri 1 Batangtoru dan waktu penelitian ini dilaksanakan lebih kurang 3 bulan lamanya. Penelitian ini menggunakan 
metode secara sistematis dan rinci. Berdasarkan fakta dan data yang akurat. Jenis penelitian yang digunakan dalam penelitian ini adalah asosiatif yaitu penelitian yang bertujuan untuk mengetahui hubungn antara dua variabel atau lebih. Penelitian ini mempunyai tingkatan yang tertinggi bila dibandingkan dengan penelitian deskriptif dan komparatif. Dengan penelitian ini maka akan dapat dibangun suatu teori yang dapat berfungsi untuk menjelaskan, meramalkan dan mengontrol suatu gejala. Objek yang dijadikan dalam penelitian ini adalah kelas X-1 yang berjumlah 40 orang peserta didik. Sementara untuk memperoleh informasi mengenai datadata penelitian ini adalah:

a. Guru mata pelajaran ekonomi

b. Peserta didik kelas X SMA Negeri 1 Batangtoru

c. Tata usaha dan pembantu staf lainnya

Secara umum prosedur penelitian dapat dibagi menjadi tiga tahap yaitu tahap persiapan, pelaksanaan dan penyelesaian. Teknik yang digunakan untuk pengumpulan data pada penelitian yaitu angket (kuesioner), yaitu bentuk pertanyaan-pertanyaan yang dibagikan kepada responden untuk memperoleh ke efektifan strategi pembelajaran eksperimen dalam kesiapan kegiatan pembelajaran di kelas X SMA Negeri 1 Batangtoru,dengan acuan bahwa angket disusun berdasarkan indikator-indikator yang berkenaan dengan variabel penelitian.

\section{Pembahasan dan Hasil}

Penelitian ini ada dua jenis data yang akan dikumpulkan untuk diolah yaitu data tentang Strategi Pembelajaran Eksperimen dan data Minat Belajar belajar pada materi manajemen peserta didik .Untuk menjaring hasil jawaban responden yang menggunakan Strategi Pembelajaran Eksperimen, penulis membuat angket berbentuk skala dengan gradasi frekuensi dibagi atas 3 (tiga) pilihan yaitu jika menjawab ya diberi skor 3, kadang-kadang diberi skor 2, tidak diberi skor 1. Sedangkan untuk mendapatkan data tentang minat belajar peserta didik di kelas X SMA Negeri 1 Batangtoru menggunakan angket yang berkenaan dengan materi pelajaran dalam bentuk essay. yang diberikan skor penilaian atas jawaban jawaban yang di berikan dimana setiap soal yang salah diberi skor 0 dan yang benar diberi skor 6,66 dimana nilai 6,66 didapatkan dari rumus

$$
N=\frac{\text { Skor maksimal }}{\text { Jumlah angket }}
$$

Hipotesis dalam penelitian ini dilakukan pengujiannya untuk membuktikan di 
terima atau di tolak kebenarannya.Dari hasil perhitungan yang dilakukan diperoleh harga $\mathrm{r}_{\mathrm{xy}}=0,991$. Jika angka indeks korelasi tersebut dikorelasikan dengan tabel " $r$ " tabel Product Moment, maka didapat bahwa taraf signifikan $5 \%$ atau tingkat kesalahan $99 \%$ dengan $\mathrm{N}=$ 40 diperoleh 0,312. Dengan demikian dapat diketahui bahwa nilai $\mathrm{r}_{\mathrm{xy}}$ hitung lebih besar daripada " $r$ " tabel yakni: 0,991> 0,312...Berdasarkan konsultasi ini, maka hipotesis yang dirumuskan dalam penelitian ini dapat diterima kebenarannya. Hal ini bahwa berarti adanya penerapan strategi pembelajaran eksperimen terhadap minat belajar peserta didik di kelas $\mathrm{X}$ SMA Negeri 1 Batangtoru. Setelah melakukan tinjauan pustaka yaitu dengan membaca buku-buku dari teoriteori yang relevan dengan variabel penelitian, maka menentukan hipotesis penelitian, yakni: "Penerapan strategi pembelajaran eksperimen dapat meningkatkan minat belajar peserta didik di kelas $\mathrm{X}$ SMA Negeri 1 Batangtoru Tahun Pelajaran 2016- 2017 ".Hasil analisa data yang dilakukan di atas diperoleh harga $r_{x y}=0,991$, jika angka indeks korelasi tersebut dikorelasikan dengan " $r$ " tabel Product Moment maka didapat bahwa taraf signifikan $5 \%$ atau tingkat kesalahan
99\% dengan $\mathrm{N}=40$ diperoleh 0,312 . Dengan demikian dapat diketahui bahwa nilai $r_{x y}$ hitung lebih besar daripada " $r$ " tabel yakni 0,991>0,312.

\section{Kesimpulan}

Berdasarkan hasil penelitian yang dilakukan dapat menarik kesimpulan yang didasarkan kepada hasil pengumpulan data, yaitu : hasil analisis data yang dilakukan di atas diperoleh harga $r_{x y}=0,991$. Jika angka indeks korelasi tersebut dikorelasikan dengan tabel " $r$ " tabel Product Moment maka didapat bahwa taraf kesalahan 99\% dan tingkata kepercayaan 5\% dengan $\mathrm{N}=40$ diperoleh 0,312. Dengan demikian dapat diketahui bahwa nilai $r$ xy hitung lebih besar daripada " $r$ " tabel yakni: $0,991>0,312$. Jadi kesimpulannya, ada peningkatan antara kedua variabel tersebut karena $\mathrm{H}_{0}$ di tolak dan $\mathrm{H}_{\mathrm{a}}$ diterima. Setelah terkumpul seluruh data dalam penelitian ini yang diperoleh di SMA Negeri 1 Batangtoru dengan menggunakan teknik angket yang disebarkan kepada peserta didik kelas X untuk mendapatkan data tentang Strategi Pembelajaran Eksperimen.

Kemudian setelah data tersebut telah terkumpul, selanjutnya menganalisa dengan menggunakan rumus korelasi Product Moment.Berdasarkan perhitungan yang 
diperoleh nilai $r$ hitung lebih besar daripada $r$ tabel. Dengan demikian dapat disimpulkan bahwa hipotesis yang diajukan dalam penelitian ini dapat diterima kebenarannya.

\section{Saran}

Dari hasil analisa yang dilakukan peneliti menyarankan :

1. Guru hendaknya

lebih meningkatkan cara mengajar dengan menggunakan berbagai metode mengajar yang dapat meningkatkan minat belajar peserta didik.

2. Kepada kepala sekolah agar melakukan pengawasan terhadap persiapan-persiapan yang harus disiapkan oleh guru sebelum melaksanakan pembelajaran khususnya tentang RPP terkait dengan mata pelajaran masingmasing guru sebelum pembelajaran dimulai.

3. Mengingat adanya kemungkinan kelemahan penelitian ini, maka perlu kiranya penelitian yang lebih lanjut dengan memperbesar atau memperluas objek yang diteliti supaya berkembang dan menarik.

\section{Daftar Pustaka}

Azwar Syaifuddin,2010, Model Penelitian, Yogyakarta: Pustaka Pelajar
Arikunto Suharsimi,2004, Dasar-dasar Evaluasi Pendidikan, Yogyakarta: Bum

Asmani , 2009, Manajemen strategi Pendidikan Anak Usia Dini, Jogjakarta: Diva pres

Daryanto,2009, Panduan Proses Pembelajaran Kreatif \& Inovatif, Jakarta : Publisher

Dahar R.W, 2006 Teori Belajar Dan Pembelajaran ,Bandung: Erlangga

Dick dan Carey. 2006 Pembelajaran dalam Implementasi Kurikulum Berbasis Kompetensi.Jakarta: 2006, Kencana.

Dzamarah, 2002 Strategi Belajar Mengajar , Jakarta : Rineka

Hamidi,2007, Metode Penelitian, Jakarta: Resda Hamalik Oemar, Istarani \& Intan Pulungan ,2015, Ensiklopedi Pendidikan medan: Media Persada

Hardjana,2005, Psikologi Pendidikan, Jakarta : Aksara Baru

Idris Shaffat, Istarani \& Intan Pulungan , 2015, Ensiklopedi Pendidikan Medan: Media Persada

M. Ngalim Purwanto, Istarani \& Intan pulungan , 2015, Ensiklopedi Pendidikan Medan: Media Persada

Oemar Muhammad AL-Taomi as-Syaibany Istarani \& Intan

Pulungan,2015,Ensiklopedi Pendidikan Medan: Media persada 
Rostiyah N.K, 2012, Strategi Belajar Mengajar, Jakarta : Rineka Cipta,

Surachma Winarno, Hadi Soetrisno,2005, Metode Penelitian, Bandung: Alfabeta

Syaiful \& Anwar Zain , 2012, Kumpulan 40 Metode Pembelajaran Medan : Media persada

Syaiful Sagala , : 2005 ,Konsep dan Makna Pembelajaran Bandung: Alfabeta

Slemato, 2010,Belajar dan Faktor-Faktor yang mempengaruhinya,Jakarta:

Rineka Cipta

Sardiman,2007, Psikologi Pendidikan Dengan Pendekatan Baru,Bandung :

Remaja Rosdakarya

Sanjaya Wina,2008,Kurikulum dan Pembelajaran, Jakarta: Prenada Media Group

Sanjaya Wina 2009. Strategi Pembelajaran; Berorientasi Standar Proses Pendidikan.Jakarta: 2009, Kencana

Skiner, 2012, Konsep dan Makna Pembelajaran, Bandung: Alfabeta,

Sujanto Agus,2007,Kiat Membelajarkan Peserta Didik, Jakarta : Gaung Persada Press

Sugiyono, 2007, Metode Penelitian Administrasi, Bandung: Alfabeta

Suharsimi Arikunto, 2006, Pengantar Prosedur Penelitian Suatu Pendekatan Praktek, Jakarta: Bumi Aksara
Yuliana Sudremi dan Nurhadi,2004, Lensa Kegiatan Ekonomi, Jakarta : PT.Bumi Aksara 